\title{
Combined effects of trans-10,cis-12 conjugated linoleic acid, propionate, and acetate on milk fat yield and composition in dairy cows
}

\author{
G. Maxin, ${ }^{\star} \dagger$ F. Glasser, $\neq^{1}$ C. Hurtaud, ${ }^{\star} \dagger$ J. L. Peyraud, ${ }^{\star} \dagger$ and H. Rulquin ${ }^{\star} \dagger$ \\ *INRA UMR 1080 Production du Lait, F-35590, Saint-Gilles, France \\ †Agrocampus Ouest, UMR 1080 Production du Lait, F-35000, Rennes, France \\ łINRA UR 1213 Herbivores, Site de Theix, F-63122, Saint-Genès-Champanelle, France
}

\section{ABSTRACT}

Diets inducing milk fat depression (MFD) are known to alter ruminal lipid metabolism, leading to the formation of specific isomers [such as trans-10, cis-12 conjugated linoleic acid (CLA)] that inhibit milk fat synthesis in lactating dairy cows. However, ruminal outflow of these isomers does not fully account for the decreases in milk fat synthesis observed during diet-induced MFD. The high-concentrate diets inducing MFD also induce a greater production of propionate, suggesting a possible inhibition of milk fat by propionate associated with trans-10,cis-12-CLA during MFD. The present experiment aimed to study the combined effects of propionate and trans-10,cis-12-CLA (both inhibitors of milk fat synthesis) on milk fat secretion and the effects of the combination of 2 nutrients with opposite effects (acetate and propionate). Six Holstein cows were used in a $6 \times 6$ Latin square design with 21 -d periods (14 d of nutrient infusion). The treatments were control; ruminal infusion of $1,500 \mathrm{~g} / \mathrm{d}$ of acetate $(\mathrm{A})$; ruminal infusion of $800 \mathrm{~g} / \mathrm{d}$ of propionate $(\mathrm{P})$; duodenal infusion of 1.60 $\mathrm{g} / \mathrm{d}$ of trans-10,cis-12-CLA (CLA); ruminal infusion of $750 \mathrm{~g} / \mathrm{d}$ of acetate $+400 \mathrm{~g} / \mathrm{d}$ of propionate $(\mathrm{A}+\mathrm{P})$; and duodenal infusion of $1.60 \mathrm{~g} / \mathrm{d}$ of trans-10, cis-12-CLA + ruminal infusion of $800 \mathrm{~g} / \mathrm{d}$ of propionate $(\mathrm{CLA}+\mathrm{P})$. The amounts of nutrients infused were chosen to induce a similar variation in milk fat content. Treatments A and $\mathrm{P}$ decreased dry matter intake. Compared with the control, P and CLA treatments decreased milk fat content and yield by $9 \%$ and $15 \%$ on average. Treatment A increased milk fat content by $6.5 \%$ but did not modify milk fat yield (because of a decrease in milk yield). The effects of A and P, and CLA and P on milk fat and fatty acid percentages and yield were additive $(\mathrm{A}+\mathrm{P}$ and CLA $+\mathrm{P}$ treatments). With a same dose of trans-10, cis12-CLA, the additional supply of propionate induced a decrease in milk fat $40 \%$ higher than that induced by

Received September 21, 2010

Accepted December 21, 2010.

${ }^{1}$ Corresponding author: frederic.glasser@clermont.inra.fr
trans-10,cis-12-CLA alone. The milk fatty acid profile obtained with $\mathrm{CLA}+\mathrm{P}$ was similar to those observed with high-concentrate diets inducing MFD. In conclusion, under our experimental conditions, the effects of the 3 nutrients were additive on mammary lipogenesis, regardless of their separate effects. We also show that propionate could contribute to the milk fat reductions unaccounted for by trans-10,cis-12-CLA during MFD induced by high-concentrate diets.

Key words: dairy cow, milk fat, nutrient

\section{INTRODUCTION}

Diets that are rich in concentrates and poor in forage have long been known to depress milk fat content in dairy cows. These reductions in milk fat content, which can reach $50 \%$ with little or no change in the yields of milk, milk protein, or lactose, are referred to as milk fat depression (MFD). Several theories have been put forward to explain the causes of MFD (reviewed in Bauman and Griinari, 2001, 2003; Shingfield et al., 2010). Currently, the most convincing one is the biohydrogenation theory: diets inducing MFD cause an alteration in ruminal lipid metabolism, leading to an increased formation of specific trans and conjugated fatty acids (FA), which inhibit lipid synthesis in the mammary gland. However, most authors acknowledge that the rumen outflow of these isomers is insufficient to fully explain the milk fat reductions observed during MFD (Roy et al., 2006; reviews in Shingfield and Griinari, 2007; and Harvatine et al., 2009), suggesting that other nutrients or mechanisms are involved (Shingfield et al., 2010).

With high-concentrate (HC) diets, the decrease in milk fat yield is associated with a decline in rumen $\mathrm{pH}$ and a shift in the rumen pattern of VFA, leading to an increase in the ruminal production of propionate (Bauman et al., 1971; Sutton et al., 2003). This increase is consistent with a higher percentage and yield of oddchain FA in milk with $\mathrm{HC}$ diets inducing MFD (Gaynor et al., 1995; Roy et al., 2006; Colman et al., 2010), similar to the increases in milk odd-chain FA reported following propionate ruminal infusions (Hurtaud et al., 
Table 1. Ingredients and chemical composition of the TMR

\begin{tabular}{lc}
\hline Item & Amount \\
\hline Ingredient, \% of DM & \\
Corn silage & 54.2 \\
Dehydrated alfalfa & 7.4 \\
Wheat bran & 5.9 \\
Soybean hulls & 4.9 \\
Corn, ground & 3.9 \\
Wheat, ground & 3.9 \\
Barley, ground & 2.2 \\
Beet pulp & 3.9 \\
Treated soybean meal & 7.9 \\
Soybean meal 48\% & 2.0 \\
Cane molasses & 1.5 \\
Urea & 0.8 \\
Vitamins and minerals & 1.5 \\
Chemical composition & \\
DM, \% & 58.6 \\
CP, \% of DM & 16.0 \\
NDF, \% of DM & 33.6 \\
ADF, \% of DM & 18.9 \\
Ether extract, \% of DM & 3.1 \\
Starch, \% of DM & 18.9 \\
NE ${ }_{\mathrm{L}}$, Mcal/kg of DM & 1.63 \\
\hline
\end{tabular}

${ }^{1}$ Calculated using published values of feed ingredients (INRA, 2007).

1998; Rigout et al., 2003; Maxin et al., 2010). This, plus the fact that propionate infusions induce a decrease in milk fat content and yield (Rulquin et al., 2007), suggests that propionate could contribute to the MFD with $\mathrm{HC}$ diets, in addition to the effects of trans-10, cis12-conjugated linoleic acid (CLA) and other trans FA intermediates.

In a previous experiment (Maxin et al., 2010), we studied the effects of propionate and trans-10,cis-12CLA supplied alone or simultaneously to dairy cows on milk fat and FA secretion. Their effects were additive, suggesting that both nutrients were involved in the modifications of milk fat secretion. However, the effect of propionate alone was not significant, probably because of the basal diet and the initial condition of the cows (very low initial milk fat content).

In the present study, we first tested whether the effects of propionate and trans-10,cis-12-CLA (both inhibitors of milk fat synthesis) were additive and would decrease milk fat more than trans-10, cis-12-CLA alone. We also tested the additivity of nutrients that have opposite effects on milk fat secretion. Such additivity might help to predict the effects of dietary changes on milk fat production and composition, provided that the changes in nutrient supply can be predicted. For this second objective we chose propionate (inhibitor) and acetate (the main substrate for de novo synthesis of FA in the mammary gland). These 3 nutrients (propionate, trans-10, cis-12-CLA, and acetate) were supplied to the cows by infusions into the rumen (for the VFA) and duodenum (for CLA), to mimic their absorption in vivo.

\section{MATERIALS AND METHODS}

\section{Animals and Diet}

Six duodenum- and rumen-fistulated Holstein cows $(643 \pm 77 \mathrm{~kg}$ of BW, $72 \pm 18$ DIM) were used for this study. Procedures for surgery, care, and use of animals for the experiment were approved by a French Ministry of Agriculture animal care committee in accordance with French regulations (Decree law 2001-464, May 29, 2001). The cows were housed in tie-stalls and milked at 0630 and $1700 \mathrm{~h}$. They were individually fed a controlled amount of a TMR formulated to meet their energy, protein, mineral, and vitamin requirements (INRA, 2007). The TMR consisted of $54.2 \%$ corn silage and $45.8 \%$ concentrates (Table 1) and was offered in equal amounts at 0830 and $1630 \mathrm{~h}$.

\section{Treatments and Experimental Design}

The experiment was conducted according to a $6 \times 6$ Latin square design with 21-d periods: $3 \mathrm{~d}$ of adjustment (progressively increasing infusions), $6 \mathrm{~d}$ of adaptation, $5 \mathrm{~d}$ of sample collection, and $7 \mathrm{~d}$ of washout to minimize carryover effects in the next period. The 6 experimental treatments were (1) control $(\mathbf{C O N}) ;(2)$ $1,500 \mathrm{~g} / \mathrm{d}$ of acetate infused into the rumen $(\mathbf{A}) ;(3) 800$ $\mathrm{g} / \mathrm{d}$ of propionate infused into the rumen $(\mathbf{P}) ;(4) 1.6$ $\mathrm{g} / \mathrm{d}$ of trans-10, cis-12-CLA infused into the duodenum (CLA); (5) $750 \mathrm{~g} / \mathrm{d}$ of acetate and $400 \mathrm{~g} / \mathrm{d}$ of propionate infused into the rumen $(\mathbf{A}+\mathbf{P})$; and (6) $1.6 \mathrm{~g} / \mathrm{d}$ of trans-10, cis-12-CLA infused into the duodenum and 800 $\mathrm{g} / \mathrm{d}$ of propionate infused into the rumen $(\mathbf{C L A}+\mathbf{P})$. The amounts of nutrients infused were chosen to induce a similar variation in milk fat content (around $4.0 \mathrm{~g} /$ $\mathrm{kg}$ ) based on published data (Rulquin et al., 2007). The trans-10, cis-12-CLA was supplied by a mixture of FA (Lutalin, BASF AG, Ludwigshafen, Germany) in which trans-10, cis-12-CLA represented $30 \%$ of total FA. The detailed composition of the FA mixture can be found in Maxin et al. (2010). The FA mixture was emulsified in skim milk with glycerol (Sigma-Aldrich Chimie, Saint-Quentin, France) and lecithin (Acros Organics, Geel, Belgium) to obtain an adequate volume $(2 \mathrm{~L} / \mathrm{d})$ for uniform and continuous infusion of trans-10, cis-12CLA. The FA mixture was refrigerated and continuously stirred to avoid line blocking. During CON, A, P, and $\mathrm{A}+\mathrm{P}$ treatments, only skim milk was infused into the duodenum.

The VFA (acetate: Carlo Erba-SDS, Val de Reuil, France; propionate: VWR, Strasbourg, France) were diluted in $50 \mathrm{~L}$ of tap water with buffers (mixture of $\mathrm{NaHCO}_{3}$ and $\mathrm{KHCO}_{3}$ ) to limit the decrease in ruminal $\mathrm{pH}$ following VFA infusions. The quantities of buffers 
were adjusted to match a solution $\mathrm{pH}$ of $4.5 \pm 0.1$. The control and CLA treatments included a solution of $\mathrm{NaCl}$ (volume of $50 \mathrm{~L}$ ) infused into the rumen, and the treatments with acetate a dietary supply of $\mathrm{NH}_{4} \mathrm{Cl}$ $(150 \mathrm{~g} / \mathrm{d})$, so that the DCAD $(\mathrm{Na}+\mathrm{K}-\mathrm{Cl})$ was positive and similar between treatments $(385 \pm 15 \mathrm{mEq} /$ $\mathrm{kg}$ of DM). All the solutions were prepared every morning and were infused and stirred continuously for $24 \mathrm{~h}$ (starting at $0800 \mathrm{~h}$ ).

\section{Measurements and Sampling}

Daily intake was determined by weighing the TMR offered and the refusals; TMR and refusals were sampled each day and oven-dried for DM determination. Corn silage and concentrate samples were pooled at the end of each period. Feed samples were then ground and analyzed for OM, CP (by the Dumas method, Association Française de Normalisation, 1997), ether extract, starch (by the Ewers polarimetric method, Association Française de Normalisation, 1985), NDF, and ADF (Van Soest et al., 1991). At each milking during infusions, milk yield was recorded and fat and protein contents were determined by infrared analysis (MilkoScan 605, Foss Electric, Hillerød, Denmark). Lactose was measured by infrared analysis on d 13 . On d 14, $100 \mathrm{~mL}$ of milk was taken from each cow at the morning and evening milkings. The morning and evening milk samples were pooled and stored at $-20^{\circ} \mathrm{C}$ before freeze-drying for analysis of FA composition. Fatty acids in freeze-dried milk were directly methylated and analyzed according to Loor et al. (2005a). Samples were then injected by the auto-sampler into a Trace-GC 2000 series gas chromatograph equipped with a flame-ionization detector (Thermo Finnigan, Les Ulis, France). Methyl esters from all samples were separated on a $100 \mathrm{~m} \times 0.25 \mathrm{~mm}$ i.d. fused-silica capillary column (CP-Sil 88, Chrompak, Middelburg, the Netherlands). Injector temperature was maintained at $250^{\circ} \mathrm{C}$ and detector temperature at $255^{\circ} \mathrm{C}$; the carrier gas was hydrogen. The FA peaks were identified by comparison of retention times with authentic fatty acid methyl ester standards (GLC 463, Nu-Chek Prep Inc., Elysian, MN; reference mixture 47885, Supelco, Bellefonte, PA). Correction factors for C4:0 to C10:0 were determined using a reference butter oil (CRM 164, Community Bureau of Reference, Brussels, Belgium). Identification of 18:1-trans, nonconjugated 18:2, and CLA isomers was carried out as described in Loor et al. (2005a).

Ruminal fluid was assayed for $\mathrm{pH}$ and VFA on $\mathrm{d} 14$ of each period. Individual sub-samples $(50 \mathrm{~mL})$ were collected from the ventral sac of the rumen via a polyvinyl chloride tube at $-0.5,+1,+2,+3,+4,+6$, and $+8 \mathrm{~h}$ after the morning meal; $\mathrm{pH}$ was measured immediately. Following filtration through 6 layers of cheesecloth, individual sub-samples were then pooled and a preservative $\left(\mathrm{H}_{2} \mathrm{PO}_{4} 5 \% \mathrm{vol} / \mathrm{vol}+\mathrm{HgCl}_{2} 1 \% \mathrm{wt} / \mathrm{vol}\right)$ was added $(10 \% \mathrm{vol} / \mathrm{vol})$. Concentrations of VFA were determined by gas chromatography (Jouany, 1982).

\section{Statistical Analysis}

Dry matter intake, milk yield, protein and fat contents were averaged over the last $5 \mathrm{~d}$ of each infusion period. One cow suffered from severe diarrhea during period 3 and 4 and another stopped eating and ruminating with treatment A. Data from these cows were excluded from the statistical analysis. Data were analyzed as a $6 \times 6$ Latin square using the MIXED procedure in SAS software (version 8.1, SAS Institute, Cary, NC). The statistical model included cow (random effect), period, treatment (fixed effects) and residual error. Multiple comparisons of means were performed with a Tukey test. Orthogonal contrasts were used to test the interactions between acetate and propionate infusions $[0.5 \times \mathrm{A}+0.5 \times \mathrm{P}-(\mathrm{A}+\mathrm{P})]$ and between trans-10,cis-12-CLA and propionate infusions [CLA + $\mathrm{P}-(\mathrm{CLA}+\mathrm{P})]$. Total milk FA yields were computed from milk fat yields $\times 0.933$ (Glasser et al., 2007).

\section{RESULTS}

\section{Intake and Rumen Parameters}

Treatments $\mathrm{A}$ and $\mathrm{P}$ significantly decreased dietary intake $(P<0.01)$ by, respectively, -2.4 and $-1.1 \mathrm{~kg}$ of DM compared with the control (Table 2). The other treatments did not alter $\mathrm{DM}$ intake. Total $\mathrm{NE}_{\mathrm{L}}$ (intake + infusion $)$ tended to be higher $(P=0.08)$ with $\mathrm{A}+\mathrm{P}$, $\mathrm{CLA}+\mathrm{P}$, and $\mathrm{P}$ treatments than with the $\mathrm{CON}, \mathrm{A}$, and CLA treatments $(+1.4 \mathrm{Mcal} / \mathrm{d}$ on average).

The ruminal concentration of total VFA was significantly higher $(P=0.05)$ with $\mathrm{A}, \mathrm{P}$, and $\mathrm{CLA}+\mathrm{P}$ treatments than with the CON, CLA, and $\mathrm{A}+\mathrm{P}$ treatments. Treatment A increased the percentage of ruminal acetate from $61.9 \%(\mathrm{CON})$ to $71.9 \%$, at the expense of all the other VFA. The infusions of propionate increased the percentage of propionate in the rumen from $20.3 \%$ of total VFA (CON) to $25.4 \%$ and $27.5 \%$ with treatments $\mathrm{P}$ and $\mathrm{CLA}+\mathrm{P}$, respectively, mainly at the expense of acetate. The percentage of butyrate and caproate also slightly decreased with the infusions of propionate, whereas the percentage of isobutyrate increased. Compared with the control, treatment $\mathrm{A}+\mathrm{P}$ did not modify the percentage of acetate and propionate in the rumen, but decreased the percentage of the other VFA (butyrate, valerate, and caproate, $P<0.05$ ). The 
Table 2. Feed intake, rumen $\mathrm{pH}$, and VFA in dairy cows infused with acetate (A), propionate (P), trans-10, cis-12-conjugated linoleic acid (CLA), acetate and propionate $(\mathrm{A}+\mathrm{P})$, or trans-10, cis-12-CLA and propionate (CLA+P)

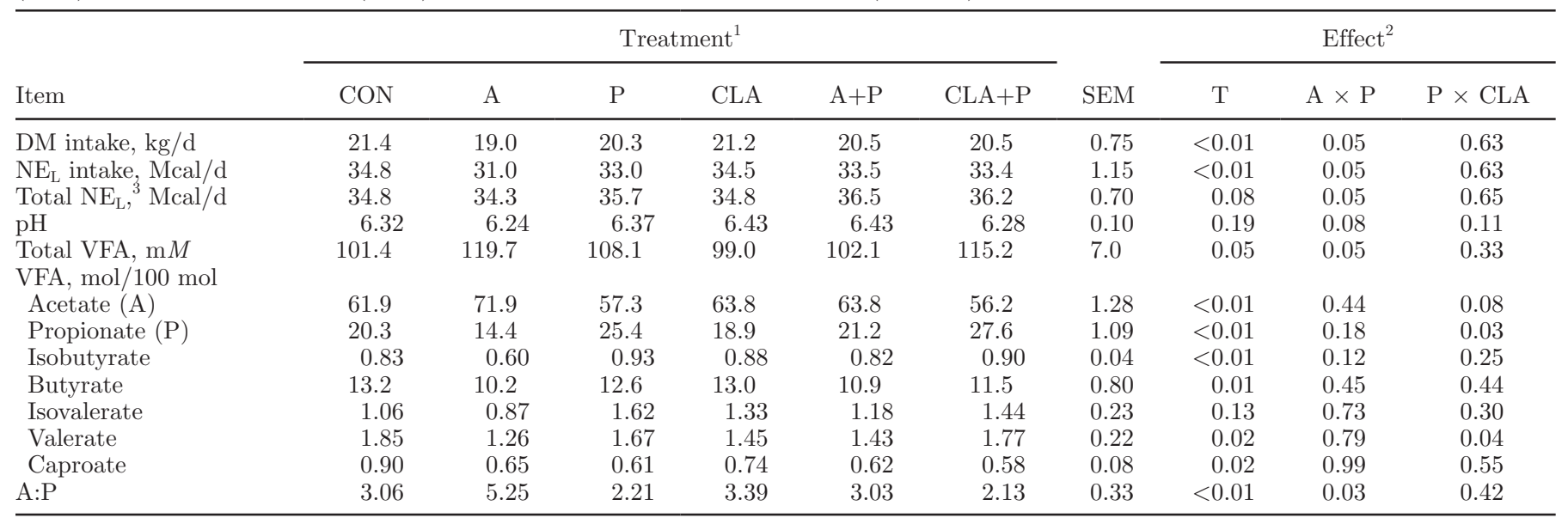

${ }^{1} \mathrm{CON}=$ control; $\mathrm{A}=$ ruminal infusion of $1,500 \mathrm{~g} / \mathrm{d}$ of acetate; $\mathrm{P}=$ ruminal infusion of $800 \mathrm{~g} / \mathrm{d}$ of propionate; CLA = duodenal infusion of 1.60 $\mathrm{g} / \mathrm{d}$ of trans-10,cis-12-CLA; $\mathrm{A}+\mathrm{P}=$ ruminal infusion of $750 \mathrm{~g} / \mathrm{d}$ of acetate and $400 \mathrm{~g} / \mathrm{d}$ of propionate; CLA $+\mathrm{P}=\mathrm{duodenal}$ infusion of trans10 ,cis-12-CLA and ruminal infusion of $800 \mathrm{~g} / \mathrm{d}$ of propionate.

${ }^{2} P$-value of the treatment effect (T; all treatments included); and interactions between $\mathrm{A}$ and $\mathrm{P}$ and between CLA and $\mathrm{P}$.

${ }^{3}$ Dietary intake + infusions.

infusion of trans-10,cis-12-CLA had no effect on rumen VFA pattern. Treatments did not differ significantly in ruminal $\mathrm{pH}$. The A:P ratio was significantly higher $(P$ $<0.05)$ for treatment $\mathrm{A}$ and lower for treatments $\mathrm{P}$ and CLA $+\mathrm{P}$ compared with CON.

\section{Milk Yield and Composition}

Treatment A decreased milk yield $(P<0.05 ;-2.3 \mathrm{~kg}$ compared with the control) unlike the other treatments (Table 3). No significant treatment effects on protein or lactose contents were observed. Protein and lactose yields decreased with treatment A, but did not vary with the other treatments compared with the control treatment.
The infusions of trans-10,cis-12-CLA and propionate alone decreased milk fat yield and content by 15 and $9 \%$, respectively, on average. Treatment A increased milk fat content by $6.5 \%$, but did not modify milk fat yield. Interactions between trans-10,cis-12-CLA and propionate or between acetate and propionate infusions were not significant for the combined infusions. Milk fat content and yield declined progressively over the 14-d infusion periods with treatments CLA and CLA+P.

\section{Milk FA Composition}

Compared with the control, infusion of acetate increased the percentage of 4:0 and 16:0 $(P<0.05)$, but decreased or tended to decrease the percentage of the

Table 3. Milk yield and composition in dairy cows infused with acetate (A), propionate (P), trans-10,cis-12-conjugated linoleic acid (CLA), acetate and propionate $(\mathrm{A}+\mathrm{P})$, or trans-10, cis-12-CLA and propionate (CLA+P)

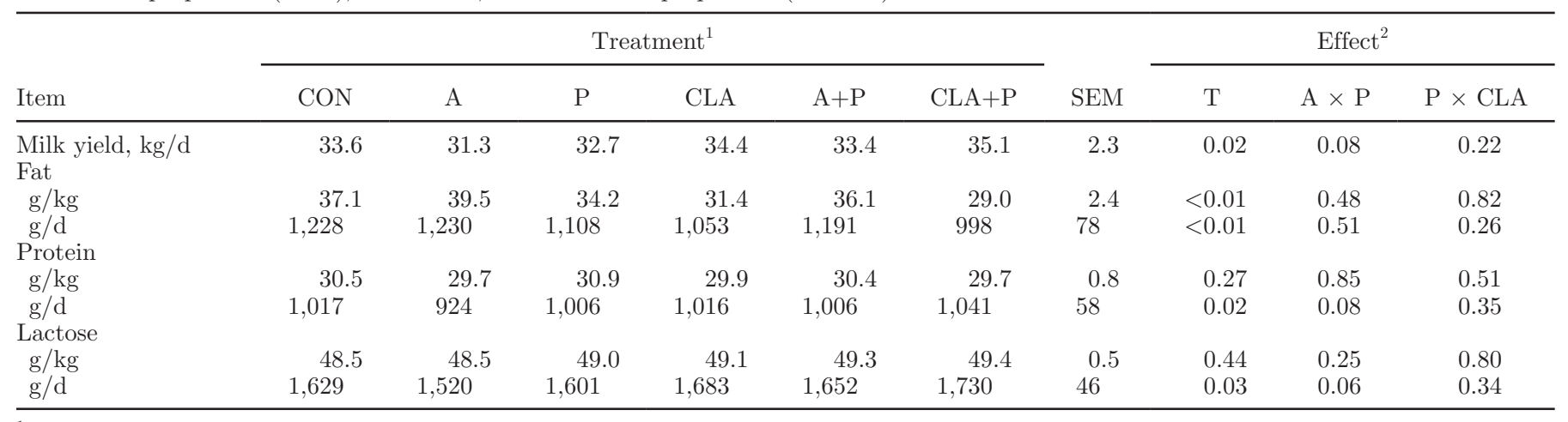

${ }^{1} \mathrm{CON}=$ control; $\mathrm{A}=$ ruminal infusion of $1,500 \mathrm{~g} / \mathrm{d}$ of acetate; $\mathrm{P}=$ ruminal infusion of $800 \mathrm{~g} / \mathrm{d}$ of propionate; CLA = duodenal infusion of 1.60 $\mathrm{g} / \mathrm{d}$ of trans-10,cis-12-CLA; A+P = ruminal infusion of $750 \mathrm{~g} / \mathrm{d}$ of acetate and $400 \mathrm{~g} / \mathrm{d}$ of propionate; CLA+P $=$ duodenal infusion of trans10,cis-12-CLA and ruminal infusion of $800 \mathrm{~g} / \mathrm{d}$ of propionate.

${ }^{2} P$-value of the treatment effect ( $\mathrm{T}$; all treatments included); and interactions between $\mathrm{A}$ and $\mathrm{P}$ and between CLA and P. 
other even short- and medium-chain FA (6:0 to 12:0; Table 4). The infusion of acetate also decreased the percentage of all the odd-chain FA (5:0 to 17:0), but did not modify the percentages of the long-chain FA (total $\mathrm{C}_{18}$ to $\mathrm{C}_{24}$ ). The infusion of propionate decreased or tended to decrease $(P \leq 0.10)$ the percentage of all even-chain FA except 16:0 and increased the percentage of all the odd-chain FA (5:0 to 17:0). The infusion of trans-10, cis-12-CLA significantly decreased the percentage of short- and medium-chain FA (6:0 to 12:0) and the percentage of the odd-chain FA $(P<0.01,5: 0$ to 17:0), and increased the percentage of total $\mathrm{C}_{18}$. Among the $\mathrm{C}_{18} \mathrm{FA}$, only 18:0, trans-12-18:1, and trans-10,cis12-CLA were significantly increased with the infusion of trans-10,cis-12-CLA. Infusions had no effect on milk $\Delta^{9}$-desaturase ratios. With the combined infusions, the interactions between trans-10,cis-12-CLA and propionate and between acetate and propionate were not significant for milk FA composition, regardless of their separate effects. When the 2 nutrients had effects of the same sign they cumulated when infused together; when they were of opposite sign they cancelled each other out. Thus, the milk FA profile for treatment CLA $+\mathrm{P}$ was characterized by a decrease in short- and mediumchain FA (6:0 to 12:0), an increase in odd-chain FA, and a slight increase in $\mathrm{C}_{18} \mathrm{FA}$ percentage. Treatment $\mathrm{A}+\mathrm{P}$ treatment decreased short- and medium-chain FA and $\mathrm{C}_{18} \mathrm{FA}$ and increased 16:0 percentage.

\section{Milk FA Yields}

Compared with the control, the infusion of acetate increased the yield of $16: 0$ and slightly decreased the yield of several other even-chain FA (Table 5, sum 6:0 to 12:0) and odd-chain FA (sum 5:0 to 19:0). Compared with the control, the infusion of propionate decreased the milk yield of all even-chain FA except 16:0 and increased the yield of odd-chain FA (sum 5:0 to 19:0). The infusion of trans-10,cis-12-CLA decreased or tended to decrease the milk yield of all FA; that is, short- and medium-chain FA (4:0 to 16:0), long-chain FA (total $\mathrm{C}_{18}$ ), and odd-chain FA (sum 5:0 to 19:0). Only the yield of 18:0 was not modified with trans-10,cis-12CLA. The amount of milk trans-10,cis-12-CLA was undetectable or very low in the $\mathrm{CON}, \mathrm{A}, \mathrm{P}$, and $\mathrm{A}+\mathrm{P}$ treatments. Milk yield of trans-10,cis-12-CLA in treatments CLA and CLA+P increased to 0.55 and 0.29 $\mathrm{g} / \mathrm{d}$, respectively, corresponding to transfer efficiencies of 34.3 and $18.1 \%$. For milk FA yields, no significant interaction was observed between trans-10, cis-12-CLA and propionate and between acetate and propionate infusions: their effects were additive with the combined infusions.

\section{DISCUSSION}

Diets inducing MFD are known to alter ruminal lipid metabolism, leading to an increased production of specific FA isomers that inhibit milk fat synthesis in lactating dairy cows (Bauman and Griinari, 2003; Shingfield and Griinari, 2007; Shingfield et al., 2010). However, these increases in FA isomers are insufficient to fully explain the observed decreases in milk fat during MFD (Shingfield et al., 2010). The HC diets inducing MFD also induce a higher production of propionate, without significantly affecting the production of acetate and butyrate (Sutton et al., 2003). To test whether an increase in propionate could contribute to CLA-induced MFD, we compared the effects on milk fat secretion of these 2 nutrients infused alone or simultaneously in dairy cows. The amounts of nutrients infused were chosen to induce a similar moderate decrease in milk fat content $(-4.0$ $\mathrm{g} / \mathrm{kg}$ ), so that the reduction induced by the 2 nutrients infused together would still be physiological (between -6.0 and $-10.0 \mathrm{~g} / \mathrm{kg}$ ). The amount of trans-10, cis-12 CLA infused was at the upper limit of what has been detected at the duodenum of cows during diet-induced MFD (Shingfield and Griinari, 2007). However, the amount of propionate infused $(800 \mathrm{~g} / \mathrm{d})$ was lower than the increase in propionate net production estimated by Sutton et al. (2003) with an HC diet (1,400 g/d).

When infused separately, both propionate and trans10,cis-12-CLA decreased milk fat content and yield. The infusion of propionate decreased milk fat content and yield by $9 \%$, which was similar to reductions observed in other experiments using the same amount of propionate (Rook and Balch, 1961; Hurtaud and Rulquin, 1999). Based on this response, the increase in propionate production reported for the $\mathrm{HC}$ diet by Sutton et al. (2003) would decrease milk fat content by 5.1 $\mathrm{g} / \mathrm{kg}$ (equivalent to $40 \%$ of the total decrease reported for this diet, $12.5 \mathrm{~g} / \mathrm{kg}$ ). The infusion of trans-10, cis12-CLA decreased milk fat secretion by $15 \%$, consistent with an expected decrease of between 14.6 and $16.9 \%$ based on relationships published elsewhere (de Veth et al., 2004; Shingfield and Griinari, 2007). The mechanisms involved in milk fat reductions with trans-10, cis12-CLA and propionate were probably different because the resulting milk FA profiles were different. Propionate decreased all the even-chain FA homogeneously regardless of the length of their carbon chain, whereas trans10, cis-12-CLA decreased the de novo FA more than the long-chain FA. Moreover, propionate increased the percentage of odd-chain FA, whereas trans-10, cis-12-CLA slightly decreased them. Several recent publications (Harvatine and Bauman, 2006; Gervais et al., 2009) demonstrated that trans-10,cis-12-CLA decreases milk 
Table 4. Milk fatty acid (FA) profiles in dairy cows infused with acetate (A), propionate (P), trans-10,cis-12-conjugated linoleic acid (CLA), acetate and propionate $(\mathrm{A}+\mathrm{P})$, or trans-10, cis-12-CLA and propionate $(\mathrm{CLA}+\mathrm{P})$

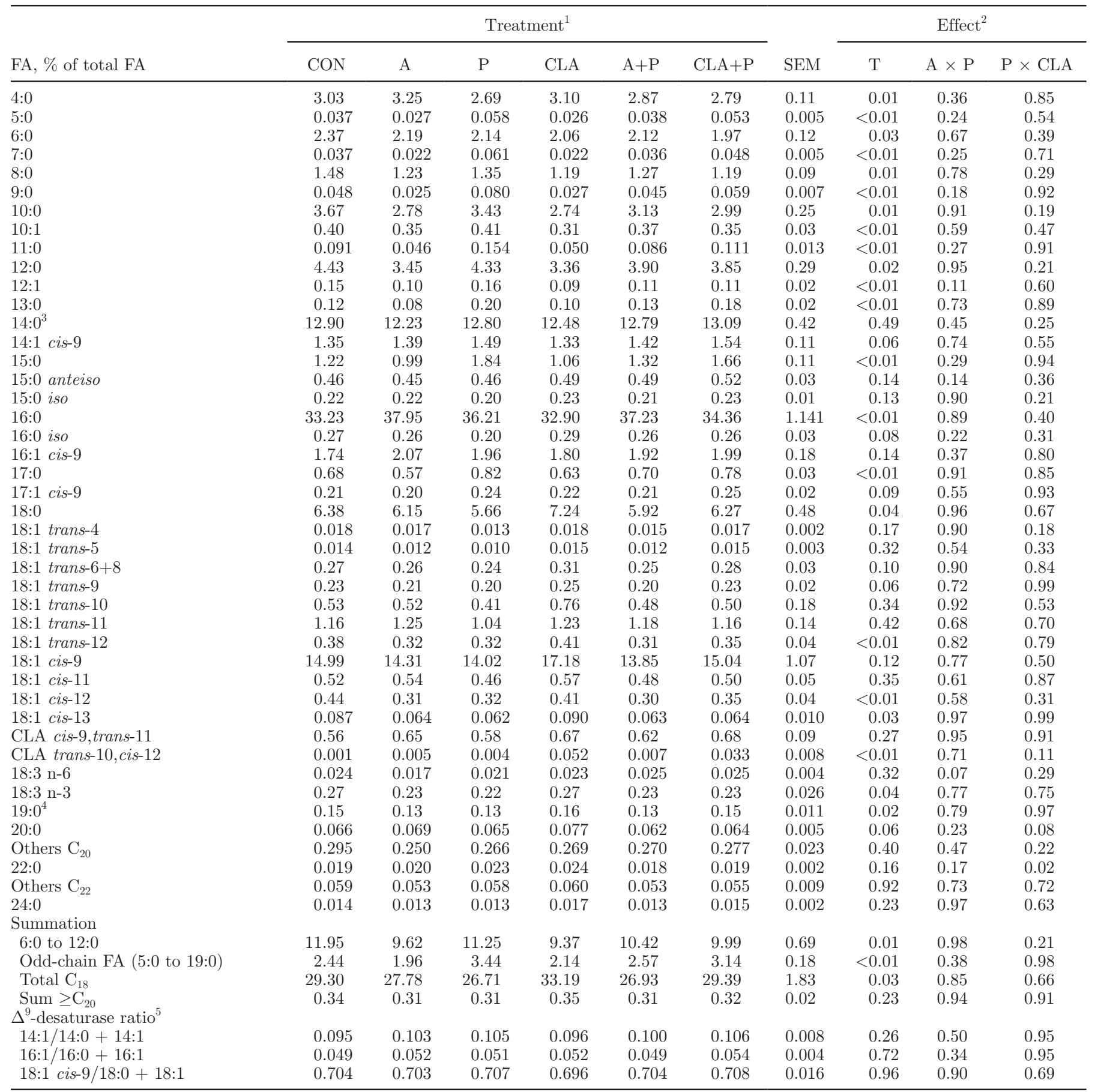

${ }^{1} \mathrm{CON}=$ control; $\mathrm{A}=$ ruminal infusion of $1,500 \mathrm{~g} / \mathrm{d}$ of acetate; $\mathrm{P}=$ ruminal infusion of $800 \mathrm{~g} / \mathrm{d}$ of propionate; CLA = duodenal infusion of 1.60 $\mathrm{g} / \mathrm{d}$ of trans-10, cis-12-CLA; A+P = ruminal infusion of $750 \mathrm{~g} / \mathrm{d}$ of acetate and $400 \mathrm{~g} / \mathrm{d}$ of propionate; CLA $+\mathrm{P}=$ duodenal infusion of trans10 ,cis-12-CLA and ruminal infusion of $800 \mathrm{~g} / \mathrm{d}$ of propionate.

${ }^{2} P$-value of the treatment effect ( $\mathrm{T}$; all treatments included); and interactions between $\mathrm{A}$ and $\mathrm{P}$ and between CLA and $\mathrm{P}$.

${ }^{3}$ Possibly collected with some $13: 1$.

${ }^{4}$ Possibly collected with some 18:1 cis-15.

${ }^{5} \Delta^{9}$-desaturase ratios were defined as [product of $\Delta^{9}$-desaturase]/[product of $\Delta^{9}$-desaturase + substrate of $\Delta^{9}$-desaturase]. 
Table 5. Milk fatty acid (FA) yields in dairy cows infused with acetate (A), propionate (P), trans-10, cis-12-conjugated linoleic acid (CLA), acetate and propionate $(\mathrm{A}+\mathrm{P})$, or trans-10, cis-12-CLA and propionate (CLA+P)

\begin{tabular}{|c|c|c|c|c|c|c|c|c|c|c|}
\hline \multirow[b]{2}{*}{$\mathrm{FA}, \mathrm{g} / \mathrm{d}$} & \multicolumn{6}{|c|}{ Treatment $^{1}$} & \multirow[b]{2}{*}{ SEM } & \multicolumn{3}{|c|}{ Effect $^{2}$} \\
\hline & $\mathrm{CON}$ & $\mathrm{A}$ & $\mathrm{P}$ & CLA & $\mathrm{A}+\mathrm{P}$ & $\mathrm{CLA}+\mathrm{P}$ & & $\mathrm{T}$ & $\mathrm{A} \times \mathrm{P}$ & $\mathrm{P} \times \mathrm{CLA}$ \\
\hline 6:0 to $12: 0$ & 285.4 & 250.4 & 249.6 & 219.5 & 257.7 & 214.1 & 22.3 & $<0.01$ & 0.59 & 0.21 \\
\hline $14: 0$ & 148.0 & 140.6 & 132.4 & 123.4 & 142.6 & 121.4 & 11.2 & 0.01 & 0.37 & 0.23 \\
\hline $16: 0$ & 379.9 & 439.5 & 375.3 & 326.9 & 412.3 & 322.6 & 30.2 & $<0.01$ & 0.78 & 0.99 \\
\hline 18:0 & 73.9 & 69.9 & 59.1 & 72.6 & 67.2 & 58.5 & 8.6 & 0.04 & 0.59 & 0.94 \\
\hline trans-10,cis-12-CLA & $<0.01$ & $<0.01$ & $<0.01$ & 0.55 & 0.08 & 0.30 & 0.11 & $<0.01$ & 0.70 & 0.11 \\
\hline Sum $\geq C_{20}$ & 5.1 & 4.5 & 4.2 & 4.2 & 4.4 & 3.8 & 0.4 & 0.02 & 0.83 & 0.29 \\
\hline
\end{tabular}

${ }^{1} \mathrm{CON}=$ control; $\mathrm{A}=$ ruminal infusion of $1,500 \mathrm{~g} / \mathrm{d}$ of acetate; $\mathrm{P}=$ ruminal infusion of $800 \mathrm{~g} / \mathrm{d}$ of propionate; CLA = duodenal infusion of 1.60 $\mathrm{g} / \mathrm{d}$ of trans-10,cis-12-CLA; $\mathrm{A}+\mathrm{P}=$ ruminal infusion of $750 \mathrm{~g} / \mathrm{d}$ of acetate and $400 \mathrm{~g} / \mathrm{d}$ of propionate; CLA+P $=$ duodenal infusion of trans10,cis-12-CLA and ruminal infusion of $800 \mathrm{~g} / \mathrm{d}$ of propionate.

${ }^{2} P$-value of the treatment effect ( $\mathrm{T}$; all treatments included) and interactions between $\mathrm{A}$ and $\mathrm{P}$ and between CLA and $\mathrm{P}$.

fat though a transcriptional downregulation of enzymes (e.g., acetyl-CoA carboxylase, lipoprotein lipase) and proteins (sterol regulatory element binding proteins, SREBP) involved in mammary lipid synthesis (review in Shingfield et al., 2010). With propionate infusions, the decrease in even-chain FA is the consequence of a decrease in plasma concentrations of the main precursors of the milk fat synthesis: acetate and BHBA for de novo-synthesized FA, NEFA and triacylglycerides for preformed FA (Rigout et al., 2003; Lemosquet et al., 2009). However, the precise mechanisms by which propionate acts on milk fat synthesis remain unknown. The increase in odd-chain FA can be explained by the increase in propionate available to the udder as a precursor of de novo synthesis of these FA (Massart-Leen et al., 1983; Emmanuel and Kennelly, 1985).

When propionate and trans-10,cis-12-CLA were infused together, their effects on milk fat secretion cumulated, leading to a greater reduction $(22 \%)$ in milk fat content and yield than when infused separately (respectively, 9 and 15\%): with the same dose of trans-10,cis-12-CLA, the supply of propionate induced a decrease in milk fat $40 \%$ higher than that induced by trans-10, cis-12-CLA alone. The lower transfer efficiency of trans-10,cis-12-CLA when infused with propionate is consistent with the decrease in milk total $\mathrm{C}_{18}$ yield induced by propionate (Table 5 ). The profile of milk FA was also altered additively, exhibiting a decrease in even short- and medium-chain FA, and an increase in odd-chain FA. These results show that these 2 inhibiting nutrients acted simultaneously on mammary lipogenesis. The profile obtained with the $\mathrm{CLA}+\mathrm{P}$ treatment is consistent with those observed with $\mathrm{HC}$ diets inducing MFD, especially the increase in odd-chain FA (Gaynor et al., 1995; Loor et al., 2005b; Roy et al., 2006; Colman et al., 2010). Hence, several results on MFD can be summarized: trans-10, cis-12CLA and other FA isomers inhibit milk fat synthesis, but they cannot fully explain the MFD induced by HC diets (reviews in Shingfield and Griinari, 2007; Harvatine et al., 2009; Shingfield et al., 2010); HC diets increase propionate production (Sutton et al., 2003); propionate infusions decrease milk fat content and yield (Bauman and Griinari, 2001; Rulquin et al., 2007); the milk fat decrease observed in the present study with $\mathrm{CLA}+\mathrm{P}$ was higher than with CLA alone, and the milk FA profiles obtained with CLA $+\mathrm{P}$ resemble those reported for HC diet-induced MFD (which is not the case with propionate alone). Thus, propionate can be partly responsible for the decrease in milk fat that is not accounted for by trans-10,cis-12-CLA in MFD induced by $\mathrm{HC}$ diets.

The second objective of this experiment was to test the additivity of the effects of 2 nutrients that have opposite effects on milk fat secretion; we chose propionate and acetate. Intraruminal infusions of acetate have been reported to enhance milk fat content and yield (Ueyama, 1972; Sheperd and Combs, 1998; review in Rulquin et al., 2007). The amount of acetate infused was chosen to induce a variation in milk fat similar to those caused by trans-10, cis-12-CLA and propionate (around $4.0 \mathrm{~g} / \mathrm{kg}$ ). However, to limit the amounts of acid infused into the rumen, to prevent ruminal perturbations and acidosis, and to keep a similar energy input, only half-amounts of acetate and propionate were infused during treatment $\mathrm{A}+\mathrm{P}$ compared with treatments $\mathrm{A}$ and $\mathrm{P}$.

In this study, acetate increased milk fat content by $6.5 \%$. This increase was similar to or slightly lower than the increases observed in earlier works with similar amounts infused. However, we did not observe the increase in milk fat yield reported by these authors $(+165 \mathrm{~g} / \mathrm{d}$ : Rook and Balch, 1961; +132 g/d: 
Rook et al., 1965; +85 g/d: Ueyama, 1972), probably because of the decrease in DM intake and milk yield that we observed with treatment A. The infusions of acetate increased the percentage and yield of 16:0, but decreased the percentages and yields of the short- and medium-chain FA (6:0 to 12:0) and the odd-chain FA. This result differs from those of other works, in which similar amounts of acetate ruminally infused to dairy cows resulted in an increase in secretion of all shortand medium-chain FA (Storry and Rook, 1965a; Storry and Rook, 1966; Orskov et al., 1969), consistent with the substrate role of acetate for mammary FA synthesis (Moore and Christie, 1979, Barber et al., 1997). In the present study, it seems that the acetate supplied by the infusions was used for the synthesis of 16:0 alone. This result was also obtained by Storry and Rook (1965b) in an experiment with intravenous infusions of acetate.

As with trans-10, cis-12-CLA and propionate, the effects of acetate and propionate were additive on both milk fat and FA secretion. When the 2 nutrients had effects of the same sign they cumulated when infused together (e.g., sum 6:0 to 12:0 yield); when the effects were of opposite sign they cancelled out (e.g., milk fat content). These results show that under our experimental conditions, the effects of all 3 nutrients on mammary lipogenesis were additive. This confirms the results obtained in our previous experiment with trans-10,cis12-CLA and propionate (Maxin et al., 2010), as well as the work of Rook et al. (1965). The latter authors studied, in the same experiment, the effects of VFA infused separately or simultaneously to dairy cows and observed that the effects of acetic, propionic, and butyric acids on milk fat content and yield were additive. The additivity of the nutrient effects, if confirmed on a larger set of nutrient combinations, could be used to estimate the milk fat changes following dietary modifications, provided that the changes in nutrient supply can be predicted.

\section{CONCLUSIONS}

This study showed that the effects of propionate and acetate, and propionate and trans-10,cis-12-CLA on milk fat secretion were additive. These findings show that propionate could contribute to the milk fat reductions unaccounted for by trans-10, cis-12-CLA during MFD induced by $\mathrm{HC}$ diets, which increase the ruminal production of propionate.

\section{ACKNOWLEDGMENTS}

We thank P. Lamberton and the farm staff for cow care and feeding, and T. Le Mouel, M. Texier (all at INRA UMR 1080 Production du Lait, Saint-Gilles,
France), and E. Tixier and C. Delavaud (both at INRA UR 1213 Herbivores, Site de Theix, Saint-Genès-Champanelle, France) for their technical assistance. This study was financially supported by Arrivé (Saint Fulgent, France), BNA (Chateau-Gontier, France), CCPA (Janzé, France), Evialis (Vannes, France), Inzo (Chierry, France), Primex (Saint-Nolff, France), Provimy France (Crevin, France) and Sanders (Bruz, France).

\section{REFERENCES}

Association Française de Normalisation (AFNOR). 1985. Dosage de l'amidon. Méthode polarimétrique. ISO 6493. AFNOR, Paris, France. http://www.afnor.org/.

Association Française de Normalisation (AFNOR). 1997. Détermination de la teneur en azote total par combustion selon le principe Dumas et calcul de la teneur en protéines brutes. NF V18120. AFNOR, Paris, France. http://www.afnor.org/.

Barber, M. C., R. A. Clegg, M. T. Travers, and R. G. Vernon. 1997. Lipid metabolism in the lactating mammary gland. Biochim. Biophys. Acta Lipids Lipid Metab. 1347:101-126.

Bauman, D. E., C. L. Davis, and H. F. Bucholtz. 1971. Propionate production in the rumen of cows fed either a control or high-grain, low-fiber diet. J. Dairy Sci. 54:1282-1287.

Bauman, D. E., and J. M. Griinari. 2001. Regulation and nutritional manipulation of milk fat: Low-fat milk syndrome. Livest. Prod. Sci. 70:15-29.

Bauman, D. E., and J. M. Griinari. 2003. Nutritional regulation of milk fat synthesis. Annu. Rev. Nutr. 23:203-227.

Colman, E., W. B. Fokkink, M. Craninx, J. R. Newbold, B. De Baets, and V. Fievez. 2010. Effect of induction of subacute ruminal acidosis on milk fat profile and rumen parameters. J. Dairy Sci. 93:4759-4773.

de Veth, M. J., J. M. Griinari, A. M. Pfeiffer, and D. E. Bauman. 2004. Effect of CLA on milk fat synthesis in dairy cows: Comparison of inhibition by methyl esters and free fatty acids, and relationships among studies. Lipids 39:365-372.

Emmanuel, B., and J. J. Kennelly. 1985. Measures of de novo synthesis of milk components from propionate in lactating goats. J. Dairy Sci. 68:312-319.

Gaynor, P. J., D. R. Waldo, A. V. Capuco, R. A. Erdman, L. W. Douglass, and B. B. Teter. 1995. Milk fat depression, the glucogenic theory, and trans-C18:1 fatty acids. J. Dairy Sci. 78:2008-2015.

Gervais, R., J. W. McFadden, A. J. Lengi, B. A. Corl, and P. Y. Chouinard. 2009. Effects of intravenous infusion of trans-10, cis-12-18:2 on mammary lipid metabolism in lactating dairy cows. J. Dairy Sci. 92:5167-5177.

Glasser, F., M. Doreau, A. Ferlay, and Y. Chilliard. 2007. Technical note: Estimation of milk fatty acid yield from milk fat data. J. Dairy Sci. 90:2302-2304.

Harvatine, K. J., and D. E. Bauman. 2006. SREBP1 and thyroid hormone responsive spot 14 (S14) are involved in the regulation of bovine mammary lipid synthesis during diet-induced milk fat depression and treatment with CLA. J. Nutr. 136:2468-2474.

Harvatine, K. J., Y. R. Boisclair, and D. E. Bauman. 2009. Recent advances in the regulation of milk fat synthesis. Animal 3:40-54.

Hurtaud, C., and H. Rulquin. 1999. Effect of the nature of energy source (propionic acid, glucose or starch) on milk production and composition in dairy cows. Ren. Rech. Rumin. 6:103-106.

Hurtaud, C., H. Rulquin, and R. Verite. 1998. Effect of level and type of energy source (volatile fatty acids or glucose) on milk yield, composition and coagulating properties in dairy cows. Reprod. Nutr. Dev. 38:315-330.

INRA. 2007. Nutrition of Cattle, Sheep and Goats: Animal NeedsValues of Feeds. Quae Editions, Paris, France.

Jouany, J. P. 1982. Volatile fatty acid and alcohol determination in digestive contents, silage juice, bacterial cultures and anaerobic fermentor contents. Sci. Aliments 2:131-144. 
Lemosquet, S., E. Delamaire, H. Lapierre, J. W. Blum, and J. L. Peyraud. 2009. Effects of glucose, propionic acid, and nonessential amino acids on glucose metabolism and milk yield in Holstein dairy cows. J. Dairy Sci. 92:3244-3257.

Loor, J. J., A. Ferlay, A. Ollier, M. Doreau, and Y. Chilliard. 2005b. Relationship among trans- and conjugated fatty acids and bovine milk fat yield due to dietary concentrate and linseed oil. J. Dairy Sci. 88:726-740.

Loor, J. J., K. Ueda, A. Ferlay, Y. Chilliard, and M. Doreau. 2005a. Intestinal flow and digestibility of trans fatty acids and conjugated linoleic acids (CLA) in dairy cows fed a high-concentrate diet supplemented with fish oil, linseed oil, or sunflower oil. Anim. Feed Sci. Technol. 119:203-225.

Massart-Leen, A. M., E. Roets, G. Peeters, and R. Verbeke. 1983. Propionate for fatty acid synthesis by the mammary gland of the lactating goat. J. Dairy Sci. 66:1445-1454.

Maxin, G., F. Glasser, and H. Rulquin. 2010. Additive effects of trans10,cis-12 conjugated linoleic acid and propionic acid on milk fat content and composition in dairy cows. J. Dairy Res. 77:295301.

Moore, J. H., and W. W. Christie. 1979. Lipid metabolism in the mammary gland or ruminant animals. Prog. Lipid Res. 17:347-395.

Orskov, E. R., W. P. Flatt, P. W. Moe, A. W. Munson, R. W. Hemken, and I. Katz. 1969. The influence of ruminal infusion of volatile fatty acids on milk yield and composition and on energy utilization by lactating cows. Br. J. Nutr. 23:443-453.

Rigout, S., C. Hurtaud, S. Lemosquet, A. Bach, and H. Rulquin. 2003. Lactational effect of propionic acid and duodenal glucose in cows. J. Dairy Sci. 86:243-253.

Rook, J. A. F., and C. C. Balch. 1961. The effects of intraruminal infusions of acetic, propionic and butyric acids on the yield and composition of the milk of the cow. Br. J. Nutr. 15:361-369.

Rook, J. A. F., C. C. Balch, and V. W. Johnson. 1965. Further observations on the effects of intraruminal infusions of volatile fatty acids and of lactic acid on the yield and composition of the milk of the cow. Br. J. Nutr. 19:93-99.

Roy, A., A. Ferlay, K. J. Shingfield, and Y. Chilliard. 2006. Examination of the persistency of milk fatty acid composition responses to plant oils in cows given different basal diets, with particular emphasis on trans-C18:1 fatty acids and isomers of conjugated linoleic acid. Anim. Sci. 82:479-492.

Rulquin, H., C. Hurtaud, S. Lemosquet, and J. L. Peyraud. 2007. Quantification of the effects of energetic nutrients on fat content of cow milk. Prod. Anim. 20:163-176.

Sheperd, A. C., and D. K. Combs. 1998. Long-term effects of acetate and propionate on voluntary feed intake by midlactation cows. J. Dairy Sci. 81:2240-2250.

Shingfield, K. J., L. Bernard, C. Leroux, and Y. Chilliard. 2010. Role of trans fatty acids in the nutritional regulation of mammary lipogenesis in ruminants. Animal 4:1140-1166.

Shingfield, K. J., and J. M. Griinari. 2007. Role of biohydrogenation intermediates in milk fat depression. Eur. J. Lipid Sci. Technol. 109:799-816.

Storry, J. E., and J. A. F. Rook. 1965a. Effect in the cow of intraruminal infusions of volatile fatty acids and of lactic acid on the secretion of the component fatty acids of the milk fat and on the composition of blood. Biochem. J. 96:210-217.

Storry, J. E., and J. A. F. Rook. 1965b. Effects of intravenous infusions of acetate, $\beta$-hydroxybutyrate, triglyceride and other metabolites on the composition of the milk fat and blood in cows. Biochem. J. $97: 879-886$.

Storry, J. E., and J. A. F. Rook. 1966. The relationship in the cow between milk-fat secretion and ruminal volatile fatty acids. Br. J. Nutr. 20:217-228.

Sutton, J. D., M. S. Dhanoa, S. V. Morant, J. France, D. J. Napper, and E. Schuller. 2003. Rates of production of acetate, propionate, and butyrate in the rumen of lactating dairy cows given normal and low-roughage diets. J. Dairy Sci. 86:3620-3633.

Ueyama, E. 1972. The effects of continuous infusion of volatile fatty acid into the rumen on the milk composition: Infusion of individual fatty acids. Jpn. J. Zootech. Sci. 43:639-647.

Van Soest, P. J., J. B. Robertson, and B. A. Lewis. 1991. Methods for dietary fiber, neutral detergent fiber, and nonstarch polysaccharides in relation to animal nutrition. J. Dairy Sci. 74:3583-3597. 